\title{
Emerging Subspecialties in Neurology: Neurodevelopmental disabilities
}

Nicolas J. Abreu, MD, David K. Urion, MD, and Miya R. Asato, MD

Neurology ${ }^{\circledR}$ 2020;95:1113-1115. doi:10.1212/WNL.0000000000010654

Correspondence

Dr. Asato

Miya.Asato@chp.edu

Approaching clinical neurology through the lens of child development and behavior is an old and well-established concept. Take for example Sir William Osler's 1894 description of the breadth of symptoms of what is now known as Sydenham chorea extending far beyond hyperkinetic movements: "The entire disposition may be changed, and the child becomes irritable, cross and unmanageable. Emotional disturbances are common, the child crying on the least provocation." ${ }^{1} \mathrm{He}$ demonstrates that adequate characterization of a child's neurologic status requires a thoughtful review of behavioral functioning compared to age-referenced norms. Through specific and systematic training in the variation of typical child development, neurologists may then begin to diagnose and manage the entire scope of neurologic disease and its impact across the lifespan. Osler drew upon 410 cases of chorea to develop his expertise; in 2001, the American Board of Psychiatry and Neurology and the American Board of Pediatrics created the subspecialty training program in neurodevelopmental disabilities (NDD) to create the future generation of neurologically trained pediatric specialists to provide comprehensive assessment, personalized treatment, and superior outcomes for children and youth with complex conditions affecting the developing nervous system.

The long path to an NDD training program recognized by the American College of Graduate Medical Education began with the creation of a distinct specialty certificate for child neurology by the American Board of Psychiatry and Neurology in 1969. In the early years of the Child Neurology Society, members recognized there was limited training and understanding of developmental disorders such as intellectual disability, autism spectrum disorder (ASD), attention-deficit/hyperactivity disorder (ADHD), and cerebral palsy, so in 1978 the Child Neurology Society established a standing committee on developmental disabilities. ${ }^{2}$ This group aimed to promote education of child neurologists in this area given the discrepancy between the sizeable volume of patients seen with these conditions and the limited formal didactic exposure over the course of training. Within the field of pediatrics, the Society for Developmental Pediatrics (SDP) was founded that same year with Arnold Capute as its first president. Dr. Capute played a fundamental role in shaping the conceptualization of current NDD training. He trained in and eventually led the developmental pediatrics program at the Kennedy Krieger Institute at Johns Hopkins University School of Medicine in Baltimore. ${ }^{3}$

With growing expertise among pediatricians across the United States in development and behavior, private funding through the W.T. Grant Foundation supported behavioral pediatrics training during pediatrics residency. These program directors formed the Society for Behavioral Pediatrics in 1982, which evolved into the Society for Developmental and Behavioral Pediatrics (SDBP) in $1994 .^{4}$ Their mission focused on clinical care, research, teaching, and child advocacy across children's cognitive, social, emotional, and physical development in the framework of their family, school, and community system.

The SDP and SDBP worked in parallel in the 1990s and by 1997, the SDP had worked with the American Board of Psychiatry and Neurology (ABPN) and the American Board of Pediatrics (ABP) to submit a proposal for the NDD subspecialty. Collaborating extensively with the ABP, the SDBP created the subspecialty of developmental-behavioral pediatrics, distinct as a

From the Division of Child Neurology (N.J.A.), Center for Gene Therapy, Nationwide Children's Hospital, Columbus, OH; Department of Neurology (D.K.U.), Boston Children's Hospital, MA; and Division of Child Neurology (M.R.A.), Departments of Pediatrics and Psychiatry, Children's Hospital of Pittsburgh of the University of Pittsburgh Medical Center, PA.

Go to Neurology.org/N for full disclosures. Funding information and disclosures deemed relevant by the authors, if any, are provided at the end of the article. 
Table Neurodevelopmental disabilities (NDD) programs as of March 8, 2020, with compiled results from personal communications with NDD program directors

\begin{tabular}{|c|c|c|c|c|}
\hline Institution & $\begin{array}{l}\text { Number of } \\
\text { categorical } \\
\text { positions }\end{array}$ & $\begin{array}{l}\text { Number of } \\
\text { advanced } \\
\text { positions }\end{array}$ & MS4 & Program focus \\
\hline $\begin{array}{l}\text { Children's National Medical Center/ } \\
\text { George Washington University }\end{array}$ & 0 & 1 & Yes & $\begin{array}{l}\text { A rigorous program with a strong focus on building skills in child } \\
\text { neurology and developmental pediatrics intermixed throughout } \\
\text { training; trainees gain mastery in diagnostics and family-based } \\
\text { care and receive substantial support for mentored research at } \\
\text { Children's National Medical Center or one of many local } \\
\text { collaborating institutions }\end{array}$ \\
\hline
\end{tabular}

\begin{tabular}{|c|c|c|c|c|}
\hline Indiana University School of Medicine & 1 & 0 & Yes & $\begin{array}{l}\text { Integrated NDD training across the full spectrum of NDD; a } \\
\text { tradition of collaborative training in combined residencies; } \\
\text { categorical program with broad, intensive inpatient and } \\
\text { outpatient clinical, teaching, and leadership experience along with } \\
\text { mentored opportunities in basic, translational, and systems } \\
\text { research; multiple faculty board certified by ABP and ABPN }\end{array}$ \\
\hline
\end{tabular}

\begin{tabular}{|c|c|c|c|c|}
\hline Johns Hopkins University & 0 & 2 & Yes & $\begin{array}{l}\text { Commitment to developing clinical expertise and positioning the } \\
\text { graduate to assume leadership in academic training, research, } \\
\text { and advocacy }\end{array}$ \\
\hline $\begin{array}{l}\text { Boston Children's Hospital/Beth Israel } \\
\text { Deaconess Medical Center/Harvard } \\
\text { Medical School }\end{array}$ & 0 & 1 & Yes & $\begin{array}{l}\text { Skill on skill spiral of training in both child neurology and } \\
\text { developmental medicine, with intermixing of both programs } \\
\text { throughout the } 4 \text { years; } 6 \text { months of research time is expected }\end{array}$ \\
\hline Oregon Health \& Sciences University & 1 & 0 & Yes & $\begin{array}{l}\text { Training physicians to become clinical, educational, and research } \\
\text { leaders for children with NDD through a collaborative 6-year } \\
\text { program integrated with child neurology and pediatrics }\end{array}$ \\
\hline $\begin{array}{l}\text { UPMC/Children's Hospital of } \\
\text { Pittsburgh }\end{array}$ & 1 & 0 & Yes & $\begin{array}{l}\text { Individually tailored clinical exposure and mentored research } \\
\text { experiences are an integral component of the NDD program, with } \\
12 \text { months of contiguous research time }\end{array}$ \\
\hline $\begin{array}{l}\text { University of Texas Southwestern } \\
\text { Medical Center }\end{array}$ & 1 & 0 & Yes & $\begin{array}{l}\text { Seeking to train NDD residents to not only be astute clinical } \\
\text { scholars, but also advocates and thought leaders in the field of } \\
\text { neurodevelopment }\end{array}$ \\
\hline $\begin{array}{l}\text { Baylor College of Medicine/Texas } \\
\text { Children's Hospital }\end{array}$ & 2 & 0 & Yes & $\begin{array}{l}\text { A rigorous program combining pediatrics, neurology, and } \\
\text { development supplemented by genetics, rehabilitation, } \\
\text { psychoeducational, psychiatric, and social work training; program } \\
\text { fosters the neurodevelopmental mindset throughout training, } \\
\text { supporting development of clinical expertise and scholarly activity } \\
\text { as well as advocacy and teaching skills }\end{array}$ \\
\hline
\end{tabular}

Abbreviations: ABP = American Board of Pediatrics; ABPN = American Board of Psychiatry and Neurology; MS4 = presence of NDD elective experiences for 4th-year medical students.

Categorical positions offer full residency training required for board certification in NDD; advanced positions in NDD begin 2 years after the match and require a separate application to 2-year preliminary general pediatrics programs. All programs offer elective experiences in NDD for interested medical students.

pediatric subspecialty from NDD, which were both simultaneously recognized by the American Board of Medical Subspecialties on March 18, 1999. ${ }^{4}$ The ABP and ABPN jointly sponsored NDD, with the examination overseen by the $A B P N$. In contrast, the $A B P$ oversees board certification in developmental and behavioral pediatrics (DBP).

The " $2+4$ " NDD training model extends the " $2+3$ " model of child neurology such that residents complete a minimum of 2 years of general pediatrics and then over 4 years of advanced postgraduate education, they develop proficiency in neurology with additional expertise in NDD across inpatient and outpatient settings. The latter 4 years integrate 12 months of adult neurology, 18 months of clinical child neurology and NDD training, and 18 months of clinical and basic science education. Required advanced rotations include at least one full-time equivalent month in child and adolescent psychiatry, neurosurgery, and neurorehabilitation. In addition, longitudinal care of both children and adults with disabilities is required, as is working in multidisciplinary teams. Scholarly activity is expected and more protected research time is typically offered compared to child neurology residency.

In contrast, DBP fellowship follows a " $3+3$ " training model of 3 years of general pediatrics and 3 years of primarily outpatient subspecialty training. Fellowship must include at least 12 months of clinical care and 12 months of scholarly activity. There are no requirements for clinical neurology or adult care.

To become a board-certified NDD specialist, physicians are expected to sit for 3 board examinations. NDD trainees are required to obtain pediatrics certification and may apply to the $\mathrm{ABP}$ in their penultimate year of training. Application for initial certification in neurology with special qualification in child neurology 
may be done in the physician's final year of NDD training. The NDD boards may only be taken once the individual has obtained these 2 certifications. However, there was a grandparenting period between 2001 and 2007 where any board-certified pediatrician or child neurologist with sufficient NDD clinical experience could take the NDD boards. In the first 2 years of offering the NDD boards, $88 \%$ of the 270 examinees were pediatricians with a special interest in NDD. ${ }^{5}$

Interested medical students apply through the Electronic Residency Application Service (ERAS) in their final year of medical school for both 2-year preliminary pediatrics programs as well as the 4-year advanced NDD programs. The majority of training sites have moved to a categorical match, such that the application process is streamlined across pediatrics and NDD, and residents work at nearby institutions throughout all 6 years. Another pathway into NDD training includes finding an open or "reserved" position in ERAS upon completion of a 3-year pediatrics residency program. While there is considerable variation in curricula and areas of focus across NDD programs across the country (table), all share a common foundation of education on developmental assessment, translational neuroscience, and neurodiagnostics in the context of a multidisciplinary team for children with complex health care needs. Within the framework of a neurobiologic model of illness, evidence-based interventions spanning behavioral therapies and novel biomedical technologies are harnessed to best care for patients. NDD graduates are expected to have greater fluency with screening, evaluation, neuropsychological testing interpretation, and management of conditions like ASD, intellectual disability, specific learning disorder, and ADHD than their child neurology colleagues, unless the latter seek additional training themselves. An NDD training program will instill competency in performing a detailed neurologic examination, analyzing laboratory results, reading neuroimaging and neurophysiologic studies, understanding molecular and anatomic pathophysiology, and interpreting complex genetic tests in the postgenomic era. Yet NDD physicians are taught to bring attention to often overlooked issues in a general child neurology practice, like medical comorbidities, care coordination, transition of care to adulthood, and systems-level problem-solving. Finally, mentored research is strongly encouraged throughout NDD education, and the additional year of training compared to child neurology allows for protected research time to explore academic interests.

There are diverse and exciting career opportunities after NDD residency. Previous residents have chosen to practice in a variety of locations, from outpatient clinics to inpatient neurology consult services. Private practice may be tailored to the physician's areas of interest, and within academic medical centers, NDD faculty have been hired within neurology, developmental medicine, pediatrics, psychiatry, or rehabilitation divisions or departments. NDD specialists are leading multidisciplinary programs in areas like traumatic brain injury, spina bifida, and cerebral palsy, as well as directing clinics with integrated clinical research on single gene disorders such as Down syndrome and
PTEN hamartoma tumor syndrome. They are championing neurodevelopmental evaluation and management of children with congenital heart disease and sickle cell anemia, building transition clinics for adults with developmental disabilities, developing novel gene therapies for neurodegenerative conditions, and transforming ASD screening best practices. None of this work is done in isolation. An NDD physician's work is by necessity one that relies on close collaboration with therapists, psychologists, psychiatrists, social workers, genetic counselors, physical medicine specialists, and other medical subspecialties in order to provide the best possible care for patients. Whether at the laboratory bench or speaking to Congressional representatives, NDD specialists have made it their life's mission to pioneer and advocate for the best possible care for patients with these disorders.

Across the United States, there is a great need for more NDD specialists, as $15 \%$ of children are living with a developmental disability. ${ }^{6}$ Yet there is also a demand for clinically informed investigators who will address the outstanding questions in basic science and translational medicine in order to move this field further. NDD training programs provide the clinical rigor and mentored research to meet both requirements, and provides a deeply fulfilling career path for young physicians.

\section{Study funding}

No targeted funding reported.

\section{Disclosure}

The authors report no disclosures relevant to the manuscript. Go to Neurology.org/N for full disclosures.

\section{Appendix Authors}

\begin{tabular}{lll}
\hline Name & Location & Contribution \\
\hline $\begin{array}{l}\text { Nicolas J. } \\
\text { Abreu, } \\
\text { MD }\end{array}$ & $\begin{array}{l}\text { Nationwide Children's } \\
\text { Hospital, Columbus, } \\
\text { OH }\end{array}$ & $\begin{array}{l}\text { Designed and conceptualized } \\
\text { study, drafted and revised the } \\
\text { manuscript }\end{array}$ \\
$\begin{array}{l}\text { David K. } \\
\text { Urion, } \\
\text { MD }\end{array}$ & $\begin{array}{l}\text { Boston Children's } \\
\text { Hospital, MA }\end{array}$ & $\begin{array}{l}\text { Designed and conceptualized } \\
\text { study, revised the manuscript, } \\
\text { including for intellectual content }\end{array}$ \\
$\begin{array}{l}\text { Miya R. } \\
\text { Asato, } \\
\text { MD }\end{array}$ & $\begin{array}{l}\text { Children's Hospital of } \\
\text { Pittsburgh at UPMC, }\end{array}$ & $\begin{array}{l}\text { Design and conceptualized study, } \\
\text { revised the manuscript, including } \\
\text { for intellectual content }\end{array}$ \\
\hline
\end{tabular}

\section{References}

1. Ashwal S, ed. The Founders of Child Neurology. 1st ed. San Francisco: Norman Publishing; 1990.

2. Accardo PJ, Capute AJ, Painter MJ. Neurodevelopmental disabilities in child neurology: the creation of a new sub-board. J Pediatr 2000;136:266-267.

3. Accardo PJ. The father of developmental pediatrics: Arnold J. Capute, MD, MPH (1923-2003). J Child Neurol 2004;19:978-981.

4. Perrin EC, Bennett FC, Wolraich ML. Subspecialty certification in developmentalbehavioral pediatrics: past and present challenges. J Dev Behav Pediatr 2000;21 $130-132$

5. Palmer FB, Percy AK, Tivnan P, Juul D, Tunnessen WW, Scheiber SC. Certification in neurodevelopmental disabilities: the development of a new subspecialty and results of the initial examinations. Ment Retard Dev Disabil Res Rev 2003;9:128-131.

6. Boyle CA, Boulet S, Schieve LA, et al. Trends in the prevalence of developmental disabilities in US children, 1997-2008. Pediatrics 2011;127:1034-1042. 


\section{Neurology}

\section{Emerging Subspecialties in Neurology: Neurodevelopmental disabilities \\ Nicolas J. Abreu, David K. Urion and Miya R. Asato \\ Neurology 2020;95;1113-1115 Published Online before print August 14, 2020 \\ DOI 10.1212/WNL.0000000000010654}

This information is current as of August 14, 2020

\section{Updated Information \&} Services

\section{References}

Subspecialty Collections

\section{Permissions \& Licensing}

Reprints including high resolution figures, can be found at: http://n.neurology.org/content/95/24/1113.full

This article cites 5 articles, 0 of which you can access for free at: http://n.neurology.org/content/95/24/1113.full\#ref-list-1

This article, along with others on similar topics, appears in the following collection(s):

\section{All Education}

http://n.neurology.org/cgi/collection/all_education All Neuropsychology/Behavior

http://n.neurology.org/cgi/collection/all_neuropsychology_behavior

\section{All Pediatric}

http://n.neurology.org/cgi/collection/all_pediatric

Developmental disorders

http://n.neurology.org/cgi/collection/developmental_disorders

History of Neurology

http://n.neurology.org/cgi/collection/history_of_neurology

Information about reproducing this article in parts (figures,tables) or in its entirety can be found online at:

http://www.neurology.org/about/about_the_journal\#permissions

Information about ordering reprints can be found online:

http://n.neurology.org/subscribers/advertise

Neurology ${ }^{\circledR}$ is the official journal of the American Academy of Neurology. Published continuously since 1951, it is now a weekly with 48 issues per year. Copyright @ 2020 American Academy of Neurology. All rights reserved. Print ISSN: 0028-3878. Online ISSN: 1526-632X.

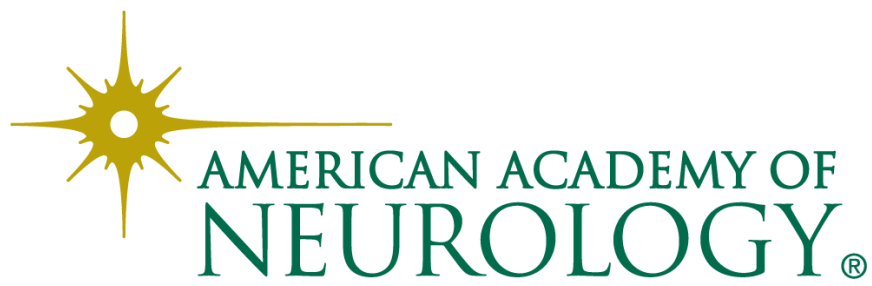

